\title{
Education Development in China: Education Return, Quality, and Equity
}

\author{
Lijia Guo ${ }^{1,2,3}$, Jiashun Huang ${ }^{4,5,6, *}$ and You Zhang ${ }^{7, *}$ \\ 1 Faculty of Human, Social and Political Science, University of Cambridge, Cambridge CB2 3RQ, UK \\ 2 Downing College, University of Cambridge, Cambridge CB2 1DQ, UK \\ 3 Department of Sociology, Yale University, New Haven, CT 06511, USA \\ 4 Institute for New Economic Thinking, Oxford Martin School, University of Oxford, Oxford OX1 3QY, UK \\ 5 School of Geography and the Environment, University of Oxford, Oxford OX1 3QY, UK \\ 6 Labor \& Worklife Program, Harvard Law School, Harvard University, Cambridge, MA 02138, USA \\ 7 Ontario Institute for Studies in Education, University of Toronto, Toronto, M5S 1V6, Canada \\ * Correspondence: jiashun.huang@sant.ox.ac.uk (J.H.); youzhang.zhang@mail.utoronto.ca (Y.Z.)
}

Received: 29 May 2019; Accepted: 2 July 2019; Published: 9 July 2019

\begin{abstract}
As the biggest developing country with the largest population in the world, China has made great achievements in education development, which has contributed tremendously to reducing poverty and boosting prosperity in the past decades. However, in the course of education development, many problems and issues have emerged, which have also been extensively studied by scholars in various fields in both China and international contexts. Among the myriad of research topics, three research foci stand out as the most concerning and studied: education return, education quality, and education equity. This paper draws on both international research literature and evidence from China to discuss education development issues including education return, education quality, and education equity, and suggests future directions for research and practice to enhance education development and to achieve a sustainable future.
\end{abstract}

Keywords: education development; education return; education quality; education equity; China

\section{Introduction}

Throughout history, human's innovations for solving various kinds of problems in order to make a better living have spread and accumulated as knowledge. Education, as a way to transmit knowledge, facilitate learning, and inspire innovation, is essential for individual and societal development. Education has long been regarded as an important driving force for economic and social development, an effective way to reduce poverty and promote prosperity, and has been listed as one of the priorities on various global development agenda, such as the United Nations' Sustainable Development Goals (SDGs) of the 2030 Agenda for Sustainable Development [1]. As its importance is well recognized, education has also long been a key concern among researchers, policy makers, and the public.

In the course of education development, many problems and issues have emerged and been widely studied from different perspectives by educationists, psychologists, economists, and sociologists. Among a myriad of research topics, three research focuses stand out as the most concerning and studied, namely education return, education quality, and education equity. These issues are central to the process and outcome of education development and are interconnected with the question of how to achieve a good education that can promote economic and social development, (i.e. high quality and equitable education that yields beneficial returns to individuals and society).

It is widely accepted that the objective and goal of education is to promote learning and help individuals master knowledge and develop skills, which consequently help them find better jobs, 
earn more income, and have a higher quality of living. Furthermore, this aggregately contributes to economic growth and an improved social environment. The economic and social returns to education for individuals and societies are regarded as important outcomes of education, and thus widely studied so as to estimate whether education has achieved its goals and if so, to what extent [2].

To achieve the goal of education, education quality is crucial and should be guaranteed [3]; however, it is often not very satisfactory and certainly will always have room for improvement. Much research has focused on this issue in this regard.

As education is so essential for human development and regarded as a human right, quality education for all is set to be a global target among many other development goals. These goals stress equal access to schools and quality education, as well as successful education achievements for all students with different backgrounds. Extensive research efforts have been made to explore and identify different education inequality patterns and the underlying reasons so as to provide references and suggestions for improvement in future policy making and implementation [4-6].

Exploring these issues and solving specific problems need to be based on specific contexts. As China is the biggest developing country with the largest population in the world, promoting education development in China contributes tremendously to reducing poverty and boosting prosperity. China has made great achievements in education development in the past decades, while at the same time it faces many long-lasting problems related to the three aforementioned key issues. Thus, this paper will draw on the evidence from China to discuss its education development issues in terms of education return, education quality, and education equity. The main objective of this paper is to provide a landscape of research on education in China, suggesting future directions for research and policymaking.

In terms of the methodologies of this study, we first review China's education development phases from a historical point of view, and then construct and illustrate the basic educational system in contemporary China. Based on data released from the Ministry of Education of the People's Republic of China, we introduce and compare the rapid expansion and the various development of different levels of education in recent years, including preschool education, primary school education, junior secondary education, senior secondary education, and college education. After this, we conduct an examination on previous studies in education return, quality, and equity. We searched and reviewed the relevant literature from the Web of Science and Google Scholar databases from 1951 to 2018, using the following keywords: "education return", "education quality", and "education equity". For each theme, we reviewed the research literature in both an international context and in China's context. By reviewing all relevant literature collected, we captured the overall picture of the research area, elaborated the line of research by introducing the most prominent and relevant work in the international context, and then specifically analyzed the research and empirical studies in China's context by looking closely at the research findings and the connections among the various studies. By outlining the three research themes on the international basis, and detailing them against the Chinese background, our work aims to present a relatively comprehensive view on China's educational development issues and research advances.

The structure of this paper is as follows. After briefly introducing the major research focuses in education development in Section 1, Section 2 provides an overview of China's education development. Sections 3-5 review research literature on education return, quality, and equity respectively, in both general and Chinese contexts. Section 6 concludes and suggests future research directions.

\section{Overview of China's Education}

\subsection{China's Education Development Phases}

In ancient China, the society was mainly based on manual labor and a small-scale agricultural economy, and the social structure was highly hierarchical. Accordingly, ancient and traditional education in China was adapted to the social structure, and its core purpose was to cultivate rulers and officials, with a focus on humanities and classics education, such as philosophy, religion, politics, history, 
and literature [7]. It was often based on individual teaching, while teachers were not professionally trained and they taught according to their own personal experience and instinct. There were different kinds of schools but they were not cohesively related.

In contrast to ancient and traditional education, modern education adapts to the modern industrial society, and its core is to popularize modern scientific and cultural knowledge education [8]. Class is the basic organizational form for teaching; teachers become professionalized, and schools of various levels are clearly classified and closely linked. Thus, ancient and modern education have significant differences on various aspects, including their education objectives, target group, curriculum, pedagogy, and education administration and management.

In stark contrast to the independent development of ancient education, the modern education system in China has its origin from other countries. The rise and establishment of modern education in the global societies started in the 17th and 18th centuries, with the emergence of national education, universal compulsory education, teacher education, the mode of class teaching, a subject-based curriculum system, and the development of educational science. However, modern education in China appeared much later than Western countries. The government of the late Qing Dynasty (at the beginning of the 20th century) issued regulations regarding school systems, signaling the transition of China's education system into a modern schooling system with clarified specifications for various types and levels of schools, number of years required for study and training, curriculum, and pedagogy.

Since the beginning of the 20th century, China underwent a turbulent transformation from an ancient feudal society towards a modern society finding its way to reconstruct the political, economic, social, and cultural systems. Education, regarded as playing a central role in advancing personal and social development, has been attached great importance in various reform agenda [9]. Thus, China first learned from the German education system via Japan, and then drew lessons from the education systems in the United States and Soviet Union. Proactively learning from the experiences of other countries was crucial for the development of the modern education system in China. Meanwhile, drawing on certain fine traditions from China's education history, combined with independent exploration and continuous innovation in response to actual problems, was another important way that the modern education system developed in China.

Starting from the late Qing dynasty, to the founding of the People's Republic of China in 1949, to the reform and opening-up policy in 1978, till today, China's modern education reform and development has lasted for over a hundred years [10] and has made huge progress and achievements. China has established a modern education system, one of the largest in the world, with its own Chinese characteristics.

\subsection{The Basic Educational System in Contemporary China}

The basic educational system adopted in China is a school education system including pre-primary education, primary education, secondary education, and higher education. According to the Compulsory Education Law of the People's Republic of China [11], a nine-year free and compulsory education is implemented by the state for all school-age children and adolescents.

Pre-primary education is usually for children aged from three to six years old. Children aged at six or seven years old shall be enrolled in school for compulsory education, covering a six-year primary education and a three-year junior secondary education. After compulsory education is the three-year senior secondary education, including general and vocational tracks. Following secondary education is higher education, which includes short-cycle tertiary education, Bachelor's level, Master's level, and doctoral level education. There is also adult education, continuing education, open and distance education, literacy programs, and special needs education. Figure 1 is an illustration of the educational system. 


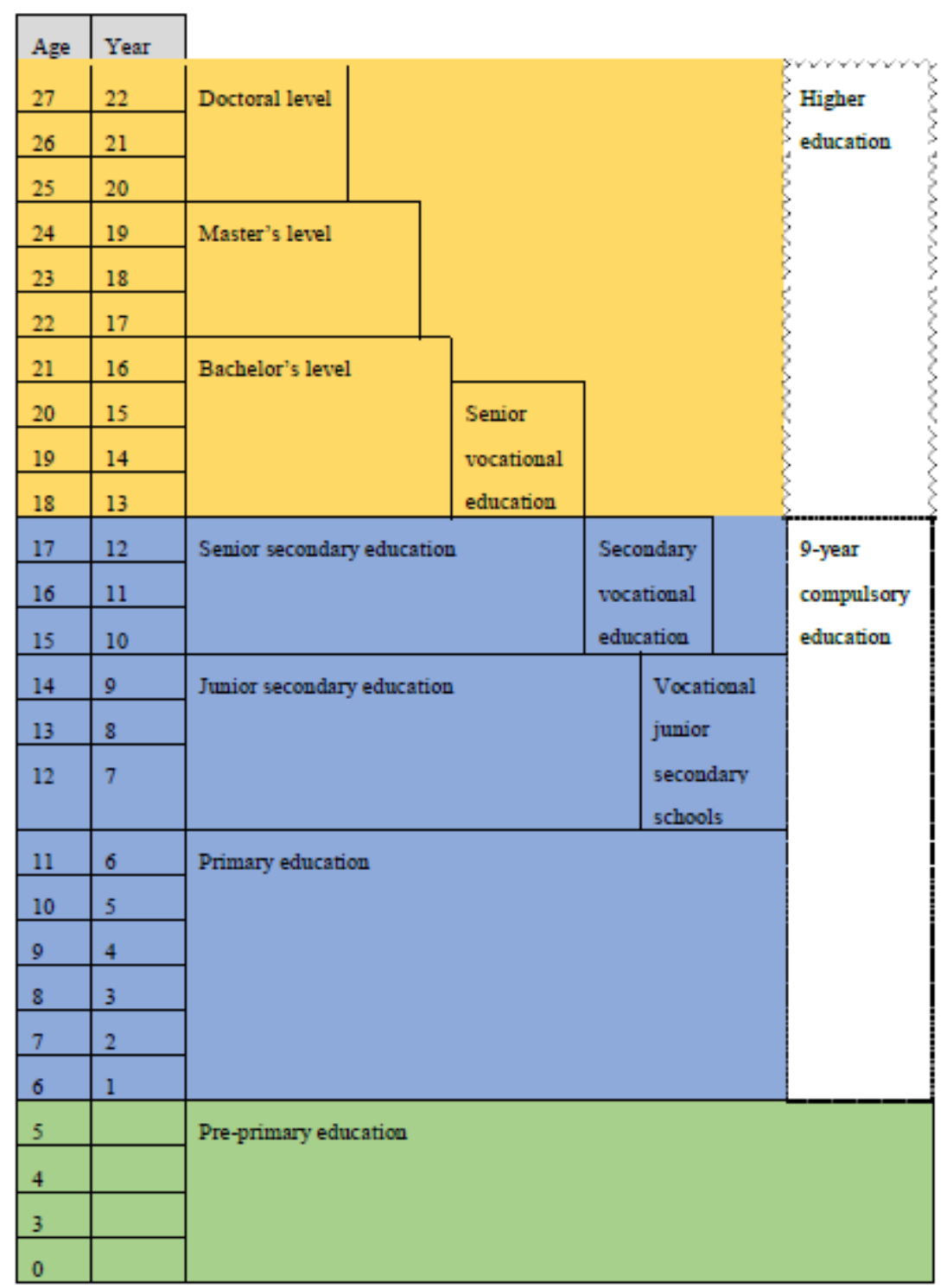

Figure 1. China's educational system. Source: compiled by the authors (MOE, P.R.C)

\subsection{China's Educational Development in Recent Years}

With the data released by the Ministry of Education of the People's Republic of China (P.R.C), the following sections will illustrate the development of China's education at various levels. As China has a huge population, basic education plays a foundational role in personal development and has therefore expanded according to the demographic changes in contemporary China, although the number of students in basic education recently experienced a slight decline due to the impact of the one-child policy. Since 1977, there has been a rapid expansion in higher education. More Chinese people had opportunities to receive a higher education in college or even study in overseas institutions.

\subsubsection{Preschool Education}

Although the number of newborn infants is slightly declining in China, the number of preschools and students in preschool education has continued to surge since 2003 (see the Figure 2). This indicates that parents pay more attention to preschool education. Two reasons stand out: first, parents have more stress in their lives and have less time to take care of their children; and second, more parents believe that their children should receive education earlier in order to have more advantages in their future education, comparable to the saying "Don't let your child lose at the starting line". 


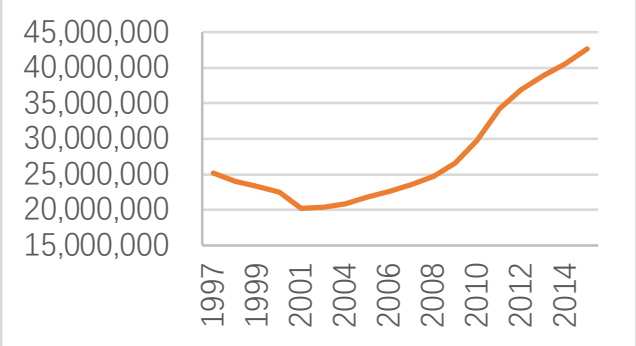

(a)

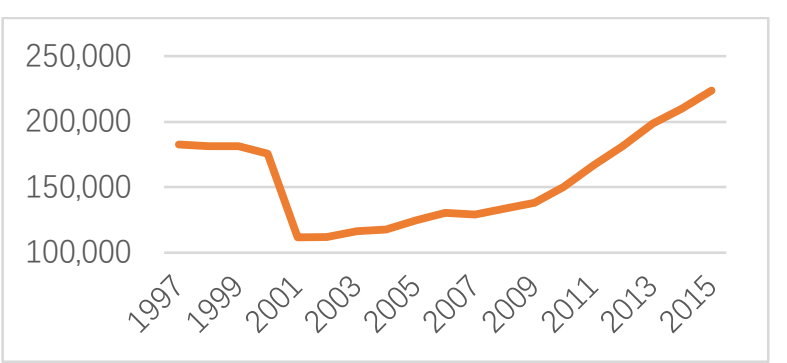

(b)

Figure 2. Preschool education: (a) the number of children in preschool education institutions; (b) the number of preschool education institutions. (Data source: Ministry of Education of the People's Republic of China (P.R.C)).

\subsubsection{Primary School Education}

As shown in the Figure 3, unlike the significant surge two decades ago, the number of students admitted by primary school education is relatively stable, remaining at around 17 million since 2004, which shows a similar trend to the demographical change. The number of primary schools is decreasing, resulting from the fact that more rural workers migrated to cities and the policy "Dismantling teaching points and combining schools".

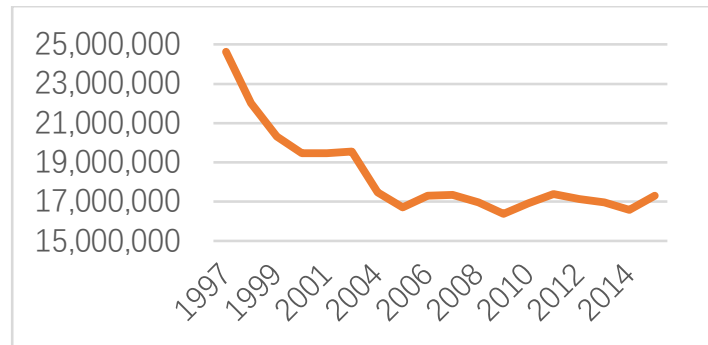

(a)

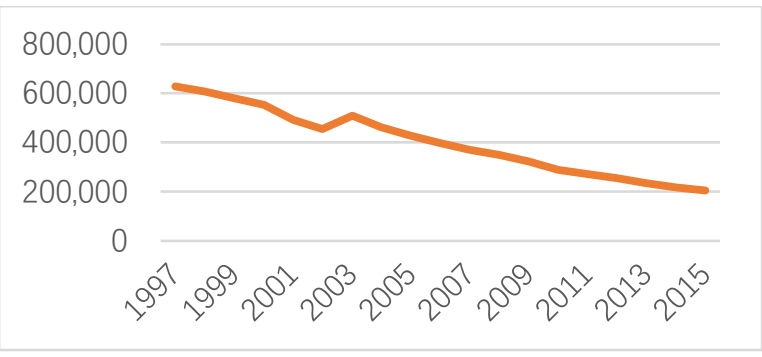

(b)

Figure 3. Primary school education: (a) the number of admitted students in primary schools; (b) the number of primary schools. (Data source: Ministry of Education of the P.R.C).

The number of teachers is also experiencing a surge. As shown in the Figure 4, the rate of students and teachers was decreasing until 2015. There were around 24 students per teacher in 1997, while in 2014, there were only around 17 students per teacher. Thus, the teacher resource in primary education is improving.

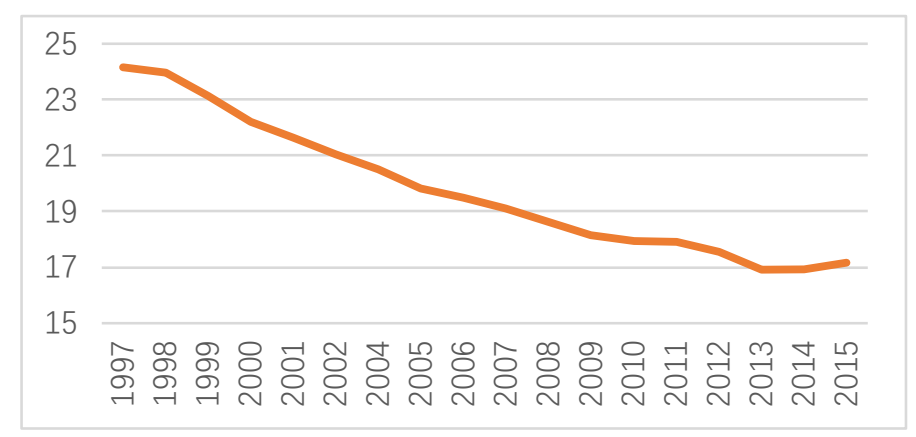

Figure 4. The student-teacher ratio in primary schools. (Date source: Ministry of Education of the P.R.C). 


\subsubsection{Junior Secondary Education}

Along with the slip in the number of admitted primary school students, the number of junior secondary school students has also experienced a decline, from the maximum number of 22.63 million in 2001 to 14.11 million in 2015, with an approximate decreasing rate of $37.6 \%$. Since the decline of the number of admitted students, the overall number of students at junior secondary school decreased from 66.18 million in 2003 to 43.12 million in 2015, with a decreasing rate of $34.84 \%$ (see the Figure 5).

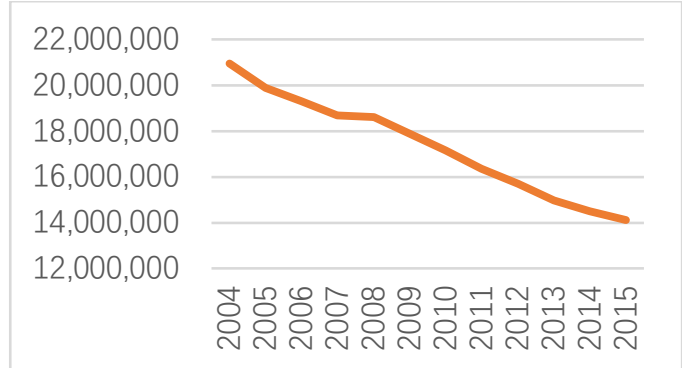

(a)

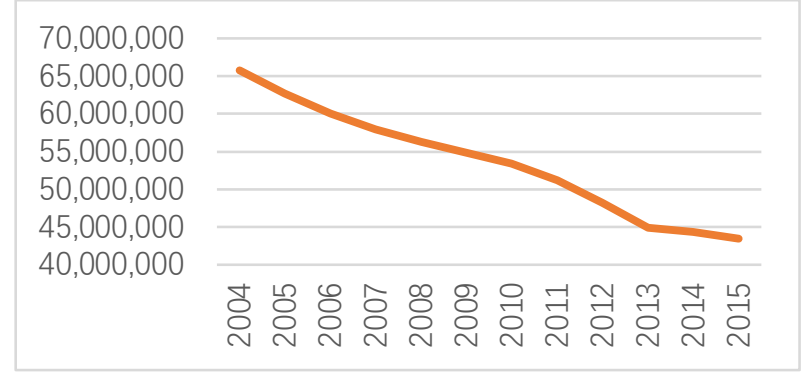

(b)

Figure 5. Junior secondary education: (a) the number of admitted students in junior secondary schools; (b) the number of total students in junior secondary schools. (Data source: Ministry of Education of the P.R.C).

\subsubsection{Senior Secondary Education}

Since the resumption of the college entrance examination in 1977, senior secondary education has been emphasized. In 2010, the senior secondary school and senior vocational schools admitted 17.04 million people, hitting a historical high, which can be seen from the Figure 6. However, as the number of junior secondary school graduations declined, the number in senior secondary education slightly decreased since 2010.

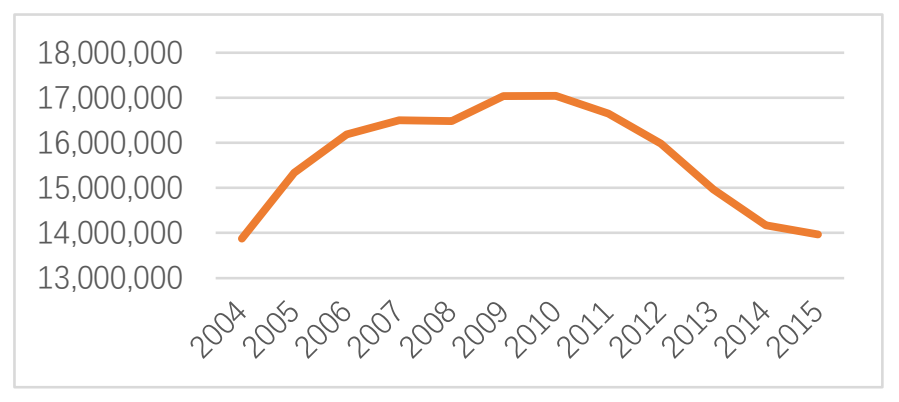

Figure 6. The number of admitted students in senior secondary school. (Data source: Ministry of Education of the P.R.C).

According to the Figure 7, as the number of teachers in senior secondary education decreased along with the decrease in student enrolment since 2010, the teaching resources have improved as the student-teacher ratio is now smaller, at about 15.88:1 in 2015. In terms of the number of senior secondary schools, it was a rapid growth during 1997-2005, and then a gradual decline to only 25,000 in 2015. 


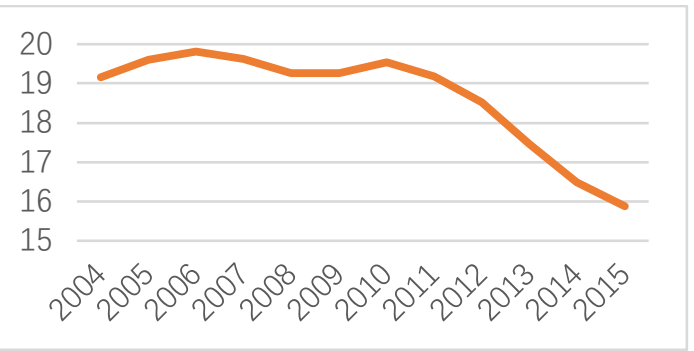

(a)

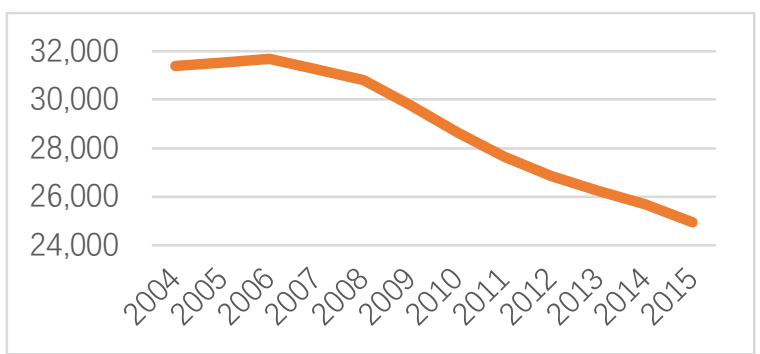

(b)

Figure 7. Senior secondary education: (a) the student-teacher ratio in senior secondary schools; (b) the number of senior secondary schools. (Date source: Ministry of Education of the P.R.C).

\subsubsection{College Education}

At the beginning of the resumption of the college entrance examination in 1977, around 5.7 million students registered to take the national college entrance examination, while only 270,000 students were admitted, with an admission rate of $4.8 \%$. Since the 21 st century, China's higher education has experienced a rapid expansion. In 2015, there were approximately 9.42 million national college examination candidates competing for about 7 million available places, with an admission rate of $74.3 \%$ (see the Figure 8 ).

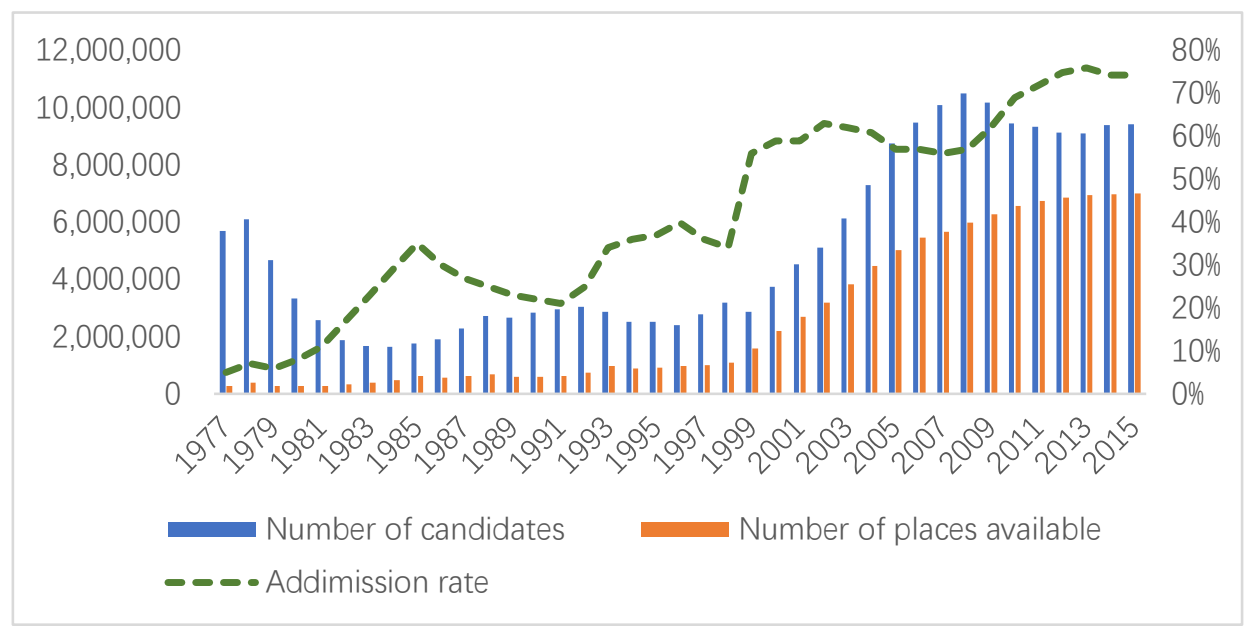

Figure 8. College admissions from 1977 to 2015. (Source: compiled by the author; reference: Ministry of Education of the P.R.C).

\subsection{China's Education Development Issues}

Although China has made great achievements in education development in recent decades, it still faces many problems, especially in terms of the three key issues: education return, education quality, and education equity. Thus, the following sections will discuss these issues and research focuses by reviewing the existing literature in both general and Chinese contexts.

\section{Education Return}

\subsection{General Research Literature on Education Return}

The benefits of, and return to, education in different dimensions and aspects have been widely studied by economists, sociologists, and educationists in the extant literature. At the individual level, education is crucial for human development from early childhood to adulthood in various aspects including development of cognitive and social skills, and it will have both pecuniary and nonpecuniary effects on different parts of their lives, such as employment and income, health, and life satisfaction. 
At the societal level, education contributes to the society by promoting economic growth and enhancing social environment.

\subsubsection{Economic Returns to Education}

Economic returns to education have been one of the predominant areas of applied economic analyses for over five decades [12]. Dating back to 1776, in the Wealth of Nations, Adam Smith mentioned the value of education in enhancing economic productivity of society, and later the Human Capital Theory from Gary Becker's Human Capital in 1964 has been influential and foundational for a field of inquiry and the economics of education [13]. As education investment is treated as a form of capital investment, financial gains are expected to be the returns to education investment by individuals and societies. Following the classical works, theoretical discussions, and significant empirical developments around 1960s and 1970s [14-17], hundreds of research papers mushroomed in this field to study the rates of return to educational investment, and to examine whether the investment decisions of individuals and governments are optimal $[18,19]$.

\section{1). Individual level}

Mincer's earnings function relating the log of earnings to schooling and experience is highly influential and widely used as the tool of empirical economic analysis to estimate the private returns to schooling [20]. The burgeoning research literature on the microeconomics of education mostly has shown a positive effect of education on the earnings of individuals, based on evidence from different datasets and various specification methods. Furthermore, it seems that the rate of return to education is larger than other investments, for example investing in businesses before investing in education [19].

\section{2). Societal level}

Various growth models have also been developed to estimate the effect of education on the economy as a whole. As education may not just be a private investment of an individual, but also a public good, it might have spill over benefits to other individuals in the same community, such as firms and industries, regions, and economies. Evidence from the extensive empirical literature on the macroeconomics of education suggests a positive effect of education on productivity. Most studies based on 'Barro' style growth regressions show that a $1 \%$ increase in school enrollment rates result in $1 \%-3 \%$ increase in per capita gross domestic product (GDP) growth. Calculations using segmented neo-classical specifications reach the result that a one-year increase in average education of the population contributes to raising the level of output per capita by $3 \%-6 \%$. The external benefits of education accruing at the macro level (i.e., national and aggregate economic growth), also provide the justification for public provision of education [21].

\subsubsection{Social Returns to Education}

Apart from economic benefits, education also exerts a non-monetary impact on other aspects of people's lives and society.

There is abundant research studying the relationship between education and health, finding evidence that an 'health-education gradient' exists [22]. Education may influence health directly by imparting more health-related knowledge, and also indirectly by improving their decision-making abilities when allocating heath inputs, gaining higher earnings to increase their ability to afford health-improving products, medical care, having healthier jobs, peers, environments and lifestyles, as well as reducing stress [23]. Brunello et al. [24] used panel data for European countries and found a protective effect of education for people aged above 50. Behrman [25] studied the causal effect of primary schooling on the HIV status of adult women in Malawi and Uganda, two East African countries with some of the highest infection rates in the world. The results indicate an increase in schooling helps reduce the probability of infection, and also has an impact on literacy, spousal education attainment in Malawi, and age of marriage and current household wealth in Uganda. 
Among the existing international research literature on early childhood education, a large number of original and synthetic studies have investigated the effect of various early childhood education and care programs on children's development in cognitive, affective, and other aspects. Consistent results of these studies are that early childhood education programs have positive effects on cognitive outcomes, social skills, and school performance at later stages of education [26,27]. These positive effects are not just immediate for the preschoolers, but also long-term and enduring later in life, linked to better outcomes such as "higher educational attainment, income, socioeconomic status (SES), and health insurance coverage, as well as lower rates of justice-system involvement and substance abuse" [28].

Cutler, Huang and Lleras-Muney [29] investigated the associations between education and later life outcomes for individuals graduating and entering the labor market in both good and bad labor market conditions. The results suggest that a higher unemployment rate upon graduation correlates with larger losses later in life, such as lower income and life satisfaction, greater obesity, and more smoking and drinking. Nevertheless, better educated individuals have substantially less losses, and education plays a protective role.

In general, education makes life better [30]. People can acquire literacy, numeracy, general and specialized knowledge, logical thinking and other broader skills, as well as a set of good values and habits in schools, which are all beneficial for human development and enable individuals to have better capacity. More educated people work in a more effective way, earn more money, lead a healthier life, have better relationships with family and friends, and make more contributions to their communities through their work and creativity.

\subsubsection{Heterogeneity in Education Return}

Although the research literature has generally shown positive returns of education, heterogeneity has also been identified in a range of studies. Firstly, the quality of education, different levels of education (including early childhood, primary, secondary, and tertiary), types (general and vocational), fields of studies, and qualifications received in different institutions, may exert diverse effects. Secondly, factors such as individual differences, gender, family background, and regional contexts may also influence education achievements and returns. Thirdly, the returns to education for wage earners and entrepreneurs in different sectors may also vary. Fourthly, the short-term and long-term impacts on education may be different. Fifthly, the specific context and the level of development in different countries may determine how the returns to education credentials change and how education contributes to economic growth. Finally, different studies may find diverse results due to the use of different data and methods.

\subsection{Education Return in China}

Based on the specific context of China, much research on education return has also been done and various findings were presented.

In terms of the external economic returns to higher education, Fan, Ma and Wang [31] have examined the relationship between individual wage changes and the percentage of college graduates in several provinces from 1991 to 2009 and have found positive external returns of about $10 \%-14 \%$ for the whole population. Within the population, however, heterogeneity exists among different groups. The returns for urban, female, and highly educated workers are found to be negligible, while returns for rural, male, poorly educated workers are significant and positive. Thus, the findings tend to suggest that public investment in education is helpful not only in increasing the individual wages, but also in reducing income inequalities. Future investment may target more on rural areas, poorly educated workers, and help enhance the capacity of women.

Regarding individual economic returns to higher education in urban China, Hu and Hibel [32] investigated and identified increasing average returns from 2003 to 2010, as well as increasing individual heterogeneity in the returns since higher education expansion, and the effects of higher education appear to be the greatest for the population at the upper end of the income distribution. 
Gao and Smyth [33] examined the effect of education expansion on the returns to schooling for migrants and non-migrants in urban China in the first decade in this century. The findings show an increase of about $2 \%-3 \%$ in the premium to education when there was an increase in educational levels, a higher education premium for non-migrants than migrants, and a higher premium for men than women. The findings reflect the increasing demand for skilled labor as China seeks to move up the value-added chain, and the wage inequality issue in urban China.

Much research has focused on urban China, while few have studied the returns in rural China and the rural-urban disparities. de Brauw and Rozelle [34] found an average return of $6.4 \%$ in rural China, and higher returns for the younger population, migrants, and post-primary schooling. Fu and Ren [35] examined how place of origin (rural or urban) and the hukou status (i.e., China's household registration (agricultural or non-agricultural)), impact income and its relationship with return to education. They have found that hukou status deeply influences an individual's years of education, occupation, job location, and income, and that the differences of the returns to education for different hukou become larger when years of education decrease, peaking at the primary education level. The findings suggest that hukou and place of origin and receiving compulsory education play a large role in determining individuals' education and human capital, and thus earnings in the labor market.

The returns to education are often estimated based on the dosage and quantity of education (i.e., education level and years of schooling), while the role of education quality is under-investigated. Zhong [36] argues that it is misleading to neglect the effect of education quality when schools and institutions are substantially varied in quality. Thus, Zhong investigated the effect of college quality on returns to higher education in China and found significant differences between colleges with different quality levels, and the effect is stronger for newer labor market entrants, which may reflect that with China's deepening transition into the market economy, wages are more responsive to the quality of human capital (i.e., the quality of education). The differences in the earning of graduates from lower quality colleges and vocational or technical schools are decreasing. The study provides implications for individual education investment decision-making and suggests more effective higher education expansion and resource allocation across various levels and types of schools and institutions.

In another empirical study on returns to education in urban China, Li, Liu and Zhang [37] first used ordinary least-squares to estimate the rate of return to years of schooling and showed the elasticity was $8.4 \%$, while the return reduced to $3.8 \%$ when they estimated the return using twins data and within-twin fixed effects model with the correction of measurement error. The results indicate that the large effect of the unobserved ability bias and family effect are often neglected in the estimation, and the true causal effect of education is relatively small. The authors contend that the reasons behind this result is due to China's highly selective and exam-oriented education system, especially high school education that mainly prepares students for the extremely competitive national college entrance examinations. As a major selection mechanism, high school education may contribute relatively less to human capital, while contrastively vocational education and college education have larger returns, which are similar to the situation in the United States.

Based on our discussions of the literature above (see the list of studies in the Table 1), we find that although education benefits individuals, the economy, and society, much research has also shown problems that impede the realization of education's value and cause disparities and inequalities in terms of returns to education for different groups of people in different countries and regions; thus, the mechanisms of how education impacts, and strategies of optimizing education investment should be attached more importance in research and considered in policy making. 
Table 1. Empirical studies on education return in China. (Source: compiled by the author).

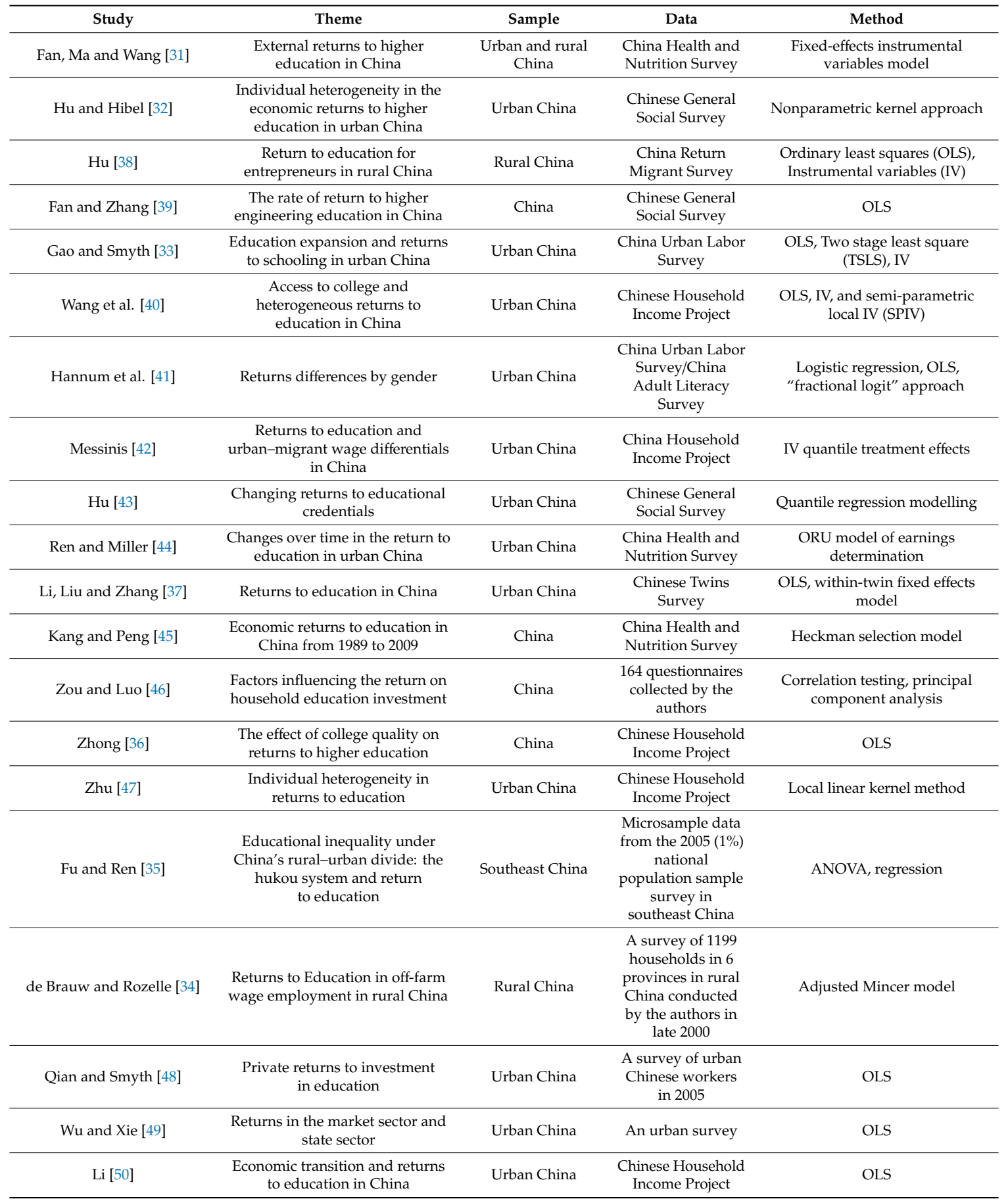

As discussed above, education yields benefit, yet there are also obstacles for achieving the goal of education, among which quality and equity are the most concerning among educators, researchers, and policy makers. When discussing education quality and equity issues, several questions come to mind. What is a good education and what goals should a good education achieve? How can quality be improved? How can China ensure the delivery of a good education and achieve the objectives? And how can China achieve a quality education for all? Promoting access and facilitating success to quality education for students with different backgrounds are critical for reducing disparities and inequalities in our society, and to ensure the delivery of quality education and education returns, all of which are required for a good education system, policy, and management. 


\section{Education Quality}

\subsection{International Literature on Education Quality}

Many discussions and debates around education are ongoing in the global education community [51-54]. International, national, and regional targets and agenda are set up to ensure the delivery of education. A good education should be able to deliver the essential knowledge and skills for human development, to help individuals develop good habits, values, and cultivate logical, critical, and independent thinking skills, and to inspire and unleash their potential and creativity, and curiosity to explore and discover new knowledge for the betterment of humankind and the world. However, the learning crisis is still prevalent today and even basic measurable skills, such as literacy and numeracy, have not been acquired by around 250 million school-aged children in the world, though half of them studied in school for at least four years. This phenomenon that poor education quality impedes basic learning goals exists in various countries and regions, such as Arab and African countries, and even in high-income OECD (Organization for Economic Co-operation and Development) countries [55].

In regard to improving learning quality, continuous efforts in research and practice are made. To enhance learning quality, measures of assessing learning outcomes are essential for tracking the learning progress and for further adjustments and improvements. For the measurement of learning outcomes, learning metrics are designed to help educators, institutions, and governments more accurately follow up on the progress of teaching and learning. Around 156 countries assess learning using examinations or participating in assessments at different levels, whether regional, national, cross-national, or international. In the recent decade, an increasing number of countries participated in large-scale numeracy and literacy international assessments, such as the Program for International Student Assessment (PISA), the Trends in Mathematics and Science Study (TIMSS), and the Progress in International Reading Literacy Study (PIRLS). There are also newly developed assessments for other skills, such as the International Computer and Information Literacy Study (ICILS), a computer-based assessment measuring digital and information literacy. There are also many regional assessments covering an increasing number of participants in Africa, Latin America, and French-speaking countries, and some citizen-based large-scale assessments, referred to as Citizen-led Basic Learning Assessments, developed by civil society organizations in India and have spread to several South Asian and African countries. Other new tools of assessment have also developed in developing countries with support from international agencies.

International longitudinal studies and surveys are established and implemented to assess and track the learning outcomes and achievements across different countries. Databases and statistics on education and learning outcomes are established, improved, and reported by various organizations with their collaboration with governments and research institutions, including the work of the Tracking Agency and Export Group, Education for All (EFA) Global Monitoring Report (GMR), and the Observatory of Learning Outcomes.

Although there are heated debates about the best approach to track learning outcomes, such as the skills, scope, targets, and scale for measuring, the increasing demand for regional and international assessments indicate an augmenting national and international attention and support on measuring and improving learning. The Learning Metrics Task Force (LMTF) convened by UNESCO has made efforts in constructing a global framework in this regard [54].

Apart from tracking learning outcomes, it is crucial to improve the process, quality, and outcomes of learning and teaching. Numerous researches have also been done on learning techniques, curriculum development, pedagogy, and use of technology in teaching and learning, which will provide much evidence and useful implications for the practice and policy in terms of what and how to teach and learn [56-61]. 


\subsection{Education Quality in China}

Quality education has long been a focus on the education reform agenda in China. Quality education refers to all-around education that promotes comprehensive human development; called "suzhi jiaoyu" in Chinese, which is contrary to "yingshi jiaoyu", the exam-oriented education has always been a problem in China's education system and widely criticized by the public. Criticisms include intense focus on rote memorization and examination, disconnection with everyday life, excessive homework load and exam pressure, teacher-centered learning, neglecting not well-performing students, and failure to cultivate creativity [62].

This phenomenon is mainly due to the Gaokao system (National College Entrance Examination), a highly selective and life-determining threshold to enter universities in China. Many students aspire to higher education, while places in universities, in particular prestigious ones, are limited. The competition to enter universities and colleges is extremely fierce. The curricula for primary and secondary school formulated by the Ministry of Education also have a large focus on the content to be covered in the Gaokao. With emphasis on exams and pressure to succeed, students work intensively and have little spare time to enjoy their childhood. Many primary and secondary school students are even found to suffer from psychological problems, and many successful college entrants lack social skills or adaptability [37]. Yin, Lu and Wang [63] found that higher education in China also features problems such as lack of emphasis on students' autonomy and independence, suggesting a reflection on the teacher-centered learning. This kind of education may help students master foundational and theoretical knowledge, but often restrains the development of personal interests, creativity, and other personal skills.

In addition, there are several other related phenomena: shadow education, private educational institutions, international schools, and studying abroad.

Shadow education, referring to private supplementary tutoring alongside regular schooling, is increasingly demanded by students who have higher expectations for educational attainment and those who have less satisfactory academic performance in schools as well as well-performing students [64]. However, private tutoring may exacerbate education inequalities as it is found that higher family income, parental education, and fewer siblings are linked to a higher tendency of and spending on private tutoring [65], and the differences of demand from students with rural and urban hukou status and different ethnicities are significant [64].

Apart from the increasing demand of private tutoring for academic subjects and preparation for exams, private tutoring and institutions for cultivating interests and hobbies, training of other skills such as musical instruments, and participation in other extracurricular activities are also highly popular among parents who wish their children to have a well-rounded development. However, both the academic and extracurricular supplementary tutoring may add a greater burden to the students' work load.

Some other parents may choose to send their children to international schools or send them to study abroad in order to avoid the stress from the Gaokao exam system and seek for a more Western-style education which they regard as better and more individualized. In 2015, there were more than 520,000 Chinese students at various educational levels studying abroad in different countries, with the US being the most popular destination. Meanwhile, international schools and private training institutions for preparing students studying abroad are also rapidly increasing in China, and China-foreign joint higher education programs and universities are increasing as well.

However, whether these trends have led to improved students' academic performance, more effective learning, cultivated multi-faceted talents, inspired their creativity, enhanced their comprehensive abilities, or increased their education returns, are still under-investigated. On the other hand, these trends may also widen the gap between students from well-off and poor families. 


\section{Education Equity}

Ensuring access to education and quality education, and reducing educational inequalities are also important issues to address. The idea of education equity is that everyone is born equal and is entitled to the rights to quality education, which enables them to develop and master essential knowledge and skills to lead a satisfied life, and as long as one works hard, they have equal opportunities to succeed.

\subsection{General Literature on Education Equity}

In term of the educational development in the world, however, there are still many out-of-schools and dropouts around the world who do not have access to education, and many at school do not receive a quality education. Although significant progress towards universal primary education has been achieved from 2000 to 2007, recent trends show a stagnation and even reversal in the progress towards the goal. Primary education enrollment and completion, and gender parity are still facing challenges. Moreover, inequalities in students' learning outcomes and education achievement and attainment are widely prevalent. There exists a pattern of inequality, as many out-of-school children and drop-outs are mostly from poor families, regions, and countries [54]. Thus, education equity in terms of entering and completing school as well as education achievement and learning quality are of great concern in many parts of the world.

In terms of the issue concerning access to education and quality education, several reasons may cause this problem. One of the key reasons is the shortage of resources, as the public and private sectors may not have or provide enough funding for the education sector to cover the school-aged population. It is recognized internationally that larger amounts of funding and more effective allocation of resources are required for achieving the goal of education for all, while funding for education is facing gaps globally. In contrast, governments, international agencies, private sectors, some philanthropists and donors tend to contribute more to healthcare than the education sector [54]. According to Steer and Ghanem [55], only 25\% of countries spend an adequate amount needed for delivering high quality education for all, and many countries with the highest unenrollment rate spend less than $3 \%$ of their gross national product (GNP) to education.

The second reason is that families of out-of-school children may not be able to provide enough support for their children to go to school. Even if the education is subsidized, families may not have much incentive to send their children to school, if they do not see a high return to education. The third reason could be due to other inequalities and policy constraints that impede equal access to quality education resources.

Many factors may lead to inequalities, including four main categories: (1) students' innate abilities, individual characteristics, motivation and effort towards study, learning techniques and resources; (2) gender and race; (3) family background and socioeconomic status (SES); and (4) social environment. Educational inequalities have long been studied, and the existing literature by different researchers have various focuses. If inequalities are caused by differences in students' innate abilities, individual characteristics, motivation and effort, learning techniques, teachers and schools are often expected to take the responsibility to provide more aid to those students who lag behind in learning. If inequalities are caused by differences in gender or race, these inequalities are often intolerable, as gender and race are originally biological attributes, which should be neutral in social sense and should not be discriminated in front of any opportunities. If inequalities are due to differences in family background and socioeconomic status, such as family income, parents' education and occupation, these inequalities are among the most widely studied phenomenon, a difficult issue to address, and the most concerned by society. As better family background and SES may mean more quality resources and more support for the students' learning, and students from disadvantaged families may have less quality resources, these inequalities may persist intergenerationally, exacerbate and widen the gaps between the rich and the poor. If the inequalities are caused by different social environments, such as different policies or systems, policy interventions may be then needed to be implemented to improve the situation. 


\subsection{Education Equity in China}

For access to education, China has made great achievements in universalizing compulsory education. A large-scale education expansion has made basic and higher education more accessible. However, acute problems are still prevalent, including high dropout rates in basic education in rural areas, social constraints and barriers to access to school in urban areas, inequalities in access to quality education and in education achievements.

Although according to the statistics from the Ministry of Education, nine-year compulsory education is almost universal in China, a few independent survey studies have examined the dropout rates. In their survey of over 7800 junior high school students in north and northwest China, Yi and Zhang [66] found dropout rates of $5.7 \%$ between grade 7 and 8 , and $9.0 \%$ between grade 8 and 9 , and even higher rates among students who were older, from a poorer family, with parents who were not in a good health condition or performed poor academically. Chung and Mason [67] found in their study regarding dropouts in primary schools in a remote mountain village in the Yunnan province, southwest China that there are also other underlying reasons besides household poverty. Perhaps due to their socioeconomically disadvantaged and culturally marginalized geographic location, students, parents, and teachers may not adjust well to the values brought about in the education system. The quality of education and lack of resources are also among the reasons.

On the other hand, in urban areas, rural migrant children have difficulty attending schools due to social and policy constraints and barriers. In the past three decades, China has witnessed rapid economic growth and urbanization, and over half of the Chinese population now live in cities with unprecedented rural-to-urban migration. However, China's unique hukou (household registration) system has caused an array of problems to migrant families, among which migrant children's education is one of the thorniest issues. As hukou to a large extent determines access to local public welfare and services, migrant children without local hukou in their current place of residency are not entitled to free compulsory education provided in the local public school districts and funded by the local government at the county/district level. Thus, many migrant children turn to migrant schools run by private businesses which often provide low-quality education, and significantly affect their academic performance [68-71]. Apart from compulsory education, hukou status is found to affect the likelihood of attending senior high school and education attainment. It is also difficult for migrant children as they go up the educational ladder because of the institutional barriers they face, as they could only take the college entrance examination in the province where they register hukou. In addition, hukou is highly correlated with family background characteristics, and also intensify the effect of family background on education for people with rural hukou, and thus further exacerbate inequalities [72]. Further, as many migrant workers find it difficult for children to attend schools in the cities where they work, many children of migrant workers become left-behind children in rural areas. Hu [73] found that absence of adult household members exerts a negative impact on high school attendance of the left-behind children, and this further influences their future education attainment.

Spatial inequalities of education due to policies such as financing and allocation of educational resources have also been identified in many studies. Due to localized financing system, funding for basic education and regional economic development levels are highly correlated, and distribution of educational resources are uneven both interprovincially and intra-provincially [74,75]. In terms of access to higher education, political and institutional structures also lead to geographical stratification and an urban-rural divide, shown from the geographical distribution of institutions and differentiated admissions procedures [76,77]. Liu [76] found that opportunities for entering higher education for students with different geographical origins are different due to the decentralized governance of the state, and the developed eastern region has more power and advantages than poor western and central areas. Jia and Ericson [78] also demonstrated in their study that "students from higher socioeconomic family backgrounds, better high schools, and more urban homes are more likely to be admitted into prestigious colleges", and that the admissions procedures and policies underlying the so-called fair Gaokao system has brought about deep social inequality. 
Apart from institutional constraint, family background and financial constraint are the other factors strengthening inequality in higher education attendance, as rising tuition costs affect the decision to enter higher education institutions for those from poor and disadvantaged families $[40,79,80]$. Li [81] found that scholastic ability and parental education are the long-term factors related to higher education attendance, while short-term financial constraints have a weaker association. Meanwhile, because tuition fees of universities are reversely associated with university quality, there exists a reverse relationship between family income and tuition costs. Students from better off families are more likely to attend better universities, and thus lower income families may have a higher burden from the university costs of their children.

As for inequalities in education achievements and attainment, many studies have presented various findings. Magnani and Zhu [82] found an increasing correlation between parental education and children's education attainment and suggested this intergenerational transmission of education may affect social mobility and cause economic inequality. It is also found that this transmission is higher among urban population as urban children mostly could at least maintain the same level of education of their parents while rural and migrant children may attain an even lower level of education than their parents, which further widens the rural and urban disparity [83]. Gender and ethnicity may also exert an impact on educational attainment, especially in disadvantaged areas. Thus, although China has made huge progress in education development in terms of improving access and attainment and reducing inequality, much effort still should be made, especially to disadvantaged and lower income populations, and to remove the institutional barriers such as the hukou system and unequal distribution of quality educational resources [84].

\section{Research Gaps and Future Directions}

In the extant literature, returns to education per se have been widely studied, while very few have examined the rate of return to the investment and expenditure on education by households, and how these investment decisions are influenced by education aspiration and expectations. Meanwhile, as there is a severe rural and urban divide in China and a large-scale rural-to-urban migration, the disparities among urban, rural, and migrant populations are also prevalent in many aspects of their lives. Thus, it is worthwhile to explore the relationship between education aspiration, investment, and return among the three groups, and the underlying reasons for any different patterns.

Along with the unprecedented economic growth in China, with more educational investment and resources, China aims to provide and achieve better domestic education quality. Meanwhile, after the reform and opening-up policy in 1978, China is becoming more open, liberal and international, and more Chinese people have the opportunity to study abroad. Especially, it is a common phenomenon that most rich business men, highly educated academics or even high status government officials would send their children to receive their education abroad. Although the overall education quality in China has improved greatly, most people still believe that the quality of overseas education in developed countries is much better than domestic education, and many domestic graduates may not have advantages compared with other Chinese students who receive a foreign education, especially in terms of innovative activities in research communities and businesses. Therefore, questions such as whether an overseas education is better quality and the determinants of the difference in quality of foreign and domestic education at various levels, await future explorations, which is critical for the future improvement of education quality.

During the process of increasing education return and improving education quality, it is crucial to consider how to achieve education equity, which can ensure basic human rights and promote well-being. Although China has achieved great success through education reform, such as providing more teaching facilities, learning opportunities, and social support, the regional inequality of education is still severe, and it is still under-investigated. To explore the education equity, given that great disparities in education resources among different geographical locations exist, it is of great significance to examine the relationship between China's education resources and education equity. Also, as education quality 
is a key factor influencing education return, it is important to explore more in depth the status quo of education quality in urban and rural areas, and whether and how education quality differs in different areas. Further, as many existing studies use old datasets, more recent datasets can be used in future studies to explore these issues. By deepening our understanding of the problems in education development through research and practice, we can better achieve our sustainable development goal for ensuring a quality education for all, ensuring human rights, enhancing human capital, improving people's living standards, and boosting economic and social development.

Author Contributions: All the authors contributed equally to this manuscript and approved the final version of the manuscript. The authors are listed in alphabetical order.

Acknowledgments: The authors would like to thank Maria Iacovou for her kind support and suggestions for improvement of the manuscript. The authors would also like to thank the editors and the anonymous reviewers for their valuable comments and suggestions. Finally, the authors would like to thank the China Scholarship Council, Swire Educational Trust, and University of Toronto Graduate Funding Package.

Conflicts of Interest: The authors declare no conflicts of interest. The funders had no role in the design of the study; in the collection, analyses, or interpretation of data; in the writing of the manuscript, or in the decision to publish the results.

\section{References}

1. Assembly, G. Sustainable development goals. In Transforming Our World: The 2030 Agenda for Sustainable Development; United Nations: New York, NY, USA, 2015.

2. Psacharopoulos, G. Returns to investment in education: A global update. World Dev. 1994, 22, 1325-1343. [CrossRef]

3. Hanushek, E.A.; Wößmann, L. The Role of Education Quality for Economic Growth; The World Bank: Washington, DC, USA, 2007.

4. Thomas, V.; Wang, Y.; Fan, X. Measuring Education Inequality: Gini Coefficients of Education; The World Bank: Washington, DC, USA, 1999.

5. Micklewright, J. Education, Inequality and Transition. Econ. Transit. 1999, 7, 343-376. [CrossRef]

6. Holsinger, D.B.; Jacob, W.J. Inequality in Education: Comparative and International Perspectives; Springer Science \& Business Media: Berlin, Germany, 2009; Volume 24.

7. Lee, T.H. Education in Traditional China: A History; Brill: Leiden, The Netherlands, 2000; Volume 13.

8. Boli, J.; Ramirez, F.O.; Meyer, J.W. Explaining the origins and expansion of mass education. Comp. Educ. Rev. 1985, 29, 145-170. [CrossRef]

9. Pepper, S. Radicalism and Education Reform in 20th-Century China: The Search for an Ideal Development Model; Cambridge University Press: Cambridge, UK, 2000.

10. Tsang, M.C. Education and National Development in China Since 1949: Oscillating Policies and Enduring Dilemmas; Chinese University Press: Sha Tin, Hong Kong, 2000; pp. 579-618.

11. Congress, N.P.S. Compulsory Education Law of the People's Republic of China; National People's Congress of the People's Republic of China: Beijing, China, 1986.

12. Dickson, M.; Harmon, C. Economic returns to education: What we know, what we don't know, and where we are going-Some brief pointers. Econ. Educ. Rev. 2011, 30, 1118-1122. [CrossRef]

13. Dearden, L.; Machin, S.; Vignoles, A. Economics of education research: A review and future prospects. Oxf. Rev. Educ. 2009, 35, 617-632. [CrossRef]

14. Schultz, T.W. Investment in human capital. Am. Econ. Rev. 1961, 51,1-17.

15. Blaug, M. The empirical status of human capital theory: A slightly jaundiced survey. J. Econ. Lit. 1976, 14, 827-855.

16. Layard, R.; Psacharopoulos, G. The screening hypothesis and the returns to education. J. Political Econ. 1974, 82, 985-998. [CrossRef]

17. Mincer, J. Investment in human capital and personal income distribution. J. Political Econ. 1958, 66, 281-302. [CrossRef]

18. Card, D. The causal effect of education on earnings. In Handbook of Labor Economics; Elsevier: Amsterdam, The Netherlands, 1999; Volume 3, pp. 1801-1863.

19. Harmon, C.; Oosterbeek, H.; Walker, I. The returns to education: Microeconomics. J. Econ. Surv. 2003, 17, 115-156. [CrossRef] 
20. Ashenfelter, O.; Harmon, C.; Oosterbeek, H. A review of estimates of the schooling/earnings relationship, with tests for publication bias. Labour Econ. 1999, 6, 453-470. [CrossRef]

21. Sianesi, B.; Reenen, J.V. The returns to education: Macroeconomics. J. Econ. Surv. 2003, 17, 157-200. [CrossRef]

22. Cutler, D.M.; Lleras-Muney, A. Understanding differences in health behaviors by education. J. Health Econ. 2010, 29, 1-28. [CrossRef] [PubMed]

23. Lochner, L. Non-Production Benefits of Education: Crime, Health, and Good Citizenship; National Bureau of Economic Research: Cambridge, MA, USA, 2011.

24. Brunello, G.; Fort, M.; Schneeweis, N.; Winter-Ebmer, R. The causal effect of education on health: What is the role of health behaviors? Health Econ. 2016, 25, 314-336. [CrossRef] [PubMed]

25. Behrman, J.A. The effect of increased primary schooling on adult women's HIV status in Malawi and Uganda: Universal Primary Education as a natural experiment. Soc. Sci. Med. 2015, 127, 108-115. [CrossRef]

26. Burger, K. How does early childhood care and education affect cognitive development? An international review of the effects of early interventions for children from different social backgrounds. Early Child. Res. Q. 2010, 25, 140-165. [CrossRef]

27. Camilli, G.; Vargas, S.; Ryan, S.; Barnett, W.S. Meta-analysis of the effects of early education interventions on cognitive and social development. Teach. Coll. Rec. 2010, 112, 579-620.

28. Reynolds, A.J.; Temple, J.A.; Ou, S.R.; Arteaga, I.A.; White, B.A. School-based early childhood education and age-28 well-being: Effects by timing, dosage, and subgroups. Science 2011, 333, 360-364. [CrossRef]

29. Cutler, D.M.; Huang, W.; Lleras-Muney, A. When does education matter? The protective effect of education for cohorts graduating in bad times. Soc. Sci. Med. 2015, 127, 63-73. [PubMed]

30. Hout, M. Social and economic returns to college education in the United States. Annu. Rev. Sociol. 2012, 38, 379-400. [CrossRef]

31. Fan, W.; Ma, Y.; Wang, L. Do We Need More Public Investment in Higher Education? Estimating the External Returns to Higher Education in China. Asian Econ. Papers 2015, 14, 88-104. [CrossRef]

32. Hu, A.; Hibel, J. Increasing heterogeneity in the economic returns to higher education in urban China. Soc. Sci. J. 2015, 52, 322-330. [CrossRef]

33. Gao, W.; Smyth, R. Education expansion and returns to schooling in urban China, 2001-2010: Evidence from three waves of the China Urban Labor Survey. J. Asia Pac. Econ. 2015, 20, 178-201. [CrossRef]

34. De Brauw, A.; Rozelle, S. Reconciling the returns to education in off-farm wage employment in rural China. Rev. Dev. Econ. 2008, 12, 57-71. [CrossRef]

35. Fu, Q.; Ren, Q. Educational inequality under China's rural-urban divide: The hukou system and return to education. Environ. Plan. A 2010, 42, 592-610. [CrossRef]

36. Zhong, H. Returns to higher education in China: What is the role of college quality? China Econ. Rev. 2011, 22, 260-275. [CrossRef]

37. Li, H.; Liu, P.W.; Zhang, J. Estimating returns to education using twins in urban China. J. Dev. Econ. 2012, 97, 494-504. [CrossRef]

38. Hu, F. Return to Education for China's Return Migrant Entrepreneurs. World Dev. 2015, 72, $296-307$. [CrossRef]

39. Fan, J.-B.; Zhang, C.-G. A study of the rate of return to higher engineering education in China. Int. J. Educ. Dev. 2015, 42, 106-114. [CrossRef]

40. Wang, X.; Fleisher, B.M.; Li, H.; Li, S. Access to college and heterogeneous returns to education in China. Econ. Educ. Rev. 2014, 42, 78-92. [CrossRef]

41. Hannum, E.; Zhang, Y.; Wang, M. Why Are Returns to Education Higher for Women than for Men in Urban China? China Q. 2013, 215, 616-640. [CrossRef]

42. Messinis, G. Returns to education and urban-migrant wage differentials in China: IV quantile treatment effects. China Econ. Rev. 2013, 26, 39-55. [CrossRef]

43. Hu, A. Proliferation of educational credentials, changing economic returns, and rising occupational education requirements: Evidence in urban China from 2003 to 2008. Int. Sociol. 2013, 28, 448-466. [CrossRef]

44. Ren, W.; Miller, P.W. Changes over time in the return to education in urban China: Conventional and ORU estimates. China Econ. Rev. 2012, 23, 154-169. [CrossRef]

45. Kang, L.; Peng, F. A selection analysis of returns to education in China. Post-Communist Econ. 2012, $24,535-554$. [CrossRef] 
46. Zou, X.; Luo, C. Factors influencing the return on household education investment: Empirical evidence from China. Qual. Quant. 2011, 45, 1531-1538. [CrossRef]

47. Zhu, R. Individual heterogeneity in returns to education in urban China during 1995-2002. Econ. Lett. 2011, 113, 84-87. [CrossRef]

48. Qian, X.; Smyth, R. Private returns to investment in education: An empirical study of urban China. Post-Communist Econ. 2008, 20, 483-501. [CrossRef]

49. Wu, X.G.; Xie, Y. Does the market pay off? Earnings returns to education in urban China. Am. Sociol. Rev. 2003, 68, 425-442.

50. Li, H.Z. Economic transition and returns to education in China. Econ. Educ. Rev. 2003, 22, 317-328. [CrossRef]

51. Rose, P. Three lessons for educational quality in post-2015 goals and targets: Clarity, measurability and equity. Int. J. Educ. Dev. 2015, 40, 289-296. [CrossRef]

52. Sayed, Y.; Ahmed, R. Education quality, and teaching and learning in the post-2015 education agenda. Int. J. Educ. Dev. 2015, 40, 330-338. [CrossRef]

53. Alexander, R.J. Teaching and learning for all? The quality imperative revisited. Int. J. Educ. Dev. 2015, 40, $250-258$. [CrossRef]

54. Winthrop, R.; Anderson, K.; Cruzalegui, I. A review of policy debates around learning in the post-2015 education and development agenda. Int. J. Educ. Dev. 2015, 40, 297-307. [CrossRef]

55. Steer, L.; Ghanem, H.; Jalbout, M. Arab youth: Missing Educational Foundations for a Productive Life; The Center for Education at the Brookings Institution: Washington, DC, USA, 2014; p. 16.

56. Young, M. Overcoming the crisis in curriculum theory: A knowledge-based approach. J. Curric. Stud. 2013, 45, 101-118. [CrossRef]

57. Mishra, P.; Koehler, M.J. Technological pedagogical content knowledge: A framework for teacher knowledge. Teach. Coll. Rec. 2006, 108, 1017-1054. [CrossRef]

58. Kirkwood, A.; Price, L. Technology-enhanced learning and teaching in higher education: What is 'enhanced'and how do we know? A critical literature review. Learn. Media Technol. 2014, 39, 6-36. [CrossRef]

59. Dunlosky, J.; Rawson, K.A.; Marsh, E.J.; Nathan, M.J.; Willingham, D.T. Improving students' learning with effective learning techniques: Promising directions from cognitive and educational psychology. Psychol. Sci. Public Interest 2013, 14, 4-58. [CrossRef]

60. Deslauriers, L.; Schelew, E.; Wieman, C. Improved learning in a large-enrollment physics class. Science 2011, 332, 862-864. [CrossRef]

61. Eichler, J.F.; Peeples, J. Flipped classroom modules for large enrollment general chemistry courses: A low barrier approach to increase active learning and improve student grades. Chem. Educ. Res. Pract. 2016,17,197-208. [CrossRef]

62. Dello-Iacovo, B. Curriculum reform and 'quality education' in China: An overview. Int. J. Educ. Dev. 2009, 29, $241-249$.

63. Yin, H.; Lu, G.; Wang, W. Unmasking the teaching quality of higher education: Students' course experience and approaches to learning in China. Assess. Eval. Higher Educ. 2014, 39, 949-970. [CrossRef]

64. Liu, J.; Bray, M. Determinants of demand for private supplementary tutoring in China: Findings from a national survey. Educ. Econ. 2017, 25, 205-218. [CrossRef]

65. Zhang, Y.; Xie, Y. Family Background, Private Tutoring, and Children's Educational Performance in Contemporary China. Chin. Sociol. Rev. 2016, 48, 64-82. [CrossRef]

66. Yi, H.; Zhang, L.; Luo, R.; Shi, Y.; Mo, D.; Chen, X.; Brinton, C.; Rozelle, S. Dropping out: Why are students leaving junior high in China's poor rural areas? Int. J. Educ. Dev. 2012, 32, 555-563. [CrossRef]

67. Chung, C.; Mason, M. Why do primary school students drop out in poor, rural China? A portrait sketched in a remote mountain village. Int. J. Educ. Dev. 2012, 32, 537-545.

68. Chen, Y.; Feng, S. Access to public schools and the education of migrant children in China. China Econ. Rev. 2013, 26, 75-88. [CrossRef]

69. Goodburn, C. Learning from migrant education: A case study of the schooling of rural migrant children in Beijing. Int. J. Educ. Dev. 2009, 29, 495-504. [CrossRef]

70. Lai, F.; Liu, C.; Luo, R.; Zhang, L.; Ma, X.; Bai, Y.; Sharbono, B.; Rozelle, S. The education of China's migrant children: The missing link in China's education system. Int. J. Educ. Dev. 2014, 37, 68-77. [CrossRef]

71. Wang, J.; Jang, W. Educational inequality among Chinese urban schools: The business ethics of private schools. Asia Pac. Bus. Rev. 2016, 22, 502-515. [CrossRef] 
72. $\mathrm{Wu}, \mathrm{X}$. The household registration system and rural-urban educational inequality in contemporary China. Chin. Sociol. Rev. 2011, 44, 31-51. [CrossRef]

73. Hu, F. Migration, remittances, and children's high school attendance: The case of rural China. Int. J. Educ. Dev. 2012, 32, 401-411. [CrossRef]

74. Xiao, J.; Liu, Z. Inequalities in the financing of compulsory education in China: A comparative study of Gansu and Jiangsu Provinces with spatial analysis. Int. J. Educ. Dev. 2014, 39, 250-263. [CrossRef]

75. Hannum, E.; Meiyan, W. Geography and educational inequality in China. China Econ. Rev. 2006, 17, $253-265$. [CrossRef]

76. Liu, Y. Geographical stratification and the role of the state in access to higher education in contemporary China. Int. J. Educ. Dev. 2015, 44, 108-117. [CrossRef]

77. Li, M.; Yang, R. Interrogating institutionalized establishments: Urban-rural inequalities in China's higher education. Asia Pac. Educ. Rev. 2013, 14, 315-323. [CrossRef]

78. Jia, Q.; Ericson, D.P. Equity and access to higher education in China: Lessons from Hunan province for university admissions policy. Int. J. Educ. Dev. 2017, 52, 97-110. [CrossRef]

79. Wu, X. Economic transition, school expansion and educational inequality in China, 1990-2000. Res. Soc. Stratif. Mobil. 2010, 28, 91-108. [CrossRef]

80. Chan, W.K.; Ngok, K. Accumulating human capital while increasing educational inequality: A study on higher education policy in China. Asia Pac. J. Educ. 2011, 31, 293-310. [CrossRef]

81. Li, W. Family background, financial constraints and higher education attendance in China. Econ. Educ. Rev. 2007, 26, 724-734. [CrossRef]

82. Magnani, E.; Zhu, R. Social mobility and inequality in urban China: Understanding the role of intergenerational transmission of education. Appl. Econ. 2015, 47, 4590-4606. [CrossRef]

83. Golley, J.; Kong, S.T. Inequality in intergenerational mobility of education in China. China World Econ. 2013, 21, 15-37. [CrossRef]

84. Yang, J.; Huang, X.; Liu, X. An analysis of education inequality in China. Int. J. Educ. Dev. 2014, 37, 2-10. [CrossRef]

(C) 2019 by the authors. Licensee MDPI, Basel, Switzerland. This article is an open access article distributed under the terms and conditions of the Creative Commons Attribution (CC BY) license (http://creativecommons.org/licenses/by/4.0/). 